\title{
"Why me and not my neighbour?" HIV/AIDS care and counselling in a traditional African context.
}

\author{
AC van Dyk, PhD, Department of Psychology, UNISA
}

\begin{abstract}
HIV/AIDS in Africa places a tremendous burden on the nursing profession. Hospitals are inundated with very sick and dying AIDS patients and nurses often find that their role as healers has shifted to a great extent to that of caregivers, counsellors and educators. AIDS also calls for nurses to go beyond the strict Western-based bio-medical model to be able to help and understand patients who come from a traditional African background. This article discusses relevant aspects of the traditional African worldview by explaining what health, sickness and sexuality mean in traditional Africa. Traditional African perceptions of the causes of illness (God, ancestors, witches, pollution and germs), perceptions of sexuality, the importance of having children, cultural beliefs inhibiting the usage of condoms, the importance of community life, as well as the controversial issue of confidentiality in Africa are discussed. The implications for AIDS care and counselling in Africa are explored and suggestions on how to use traditional beliefs and customs to the advantage of AIDS education, are offered.'
\end{abstract}

\section{Opsomming}

HIV/VIGS in Afrika plaas ' $n$ geweldige lading op die verpleegkunde professie. Hospitale word oorlaai met siek en sterwende VIGS pasiënte, en verpleegkundiges voel dikwels dat hul rol as helers tot ' $\mathrm{n}$ groot mate verskuif het na dié van versorgers, beraders en opvoeders. VIGS vereis ook van verpleegkundiges om verder te kyk as die streng Westers-gebaseerde bio-mediese model sodat hulle pasiënte met ' $n$ tradisionele Afrika agtergrond kan help en verstaan. Hierdie artikel bespreek relevante aspekte van die tradisionele Afrika wêreldbeskouing deur te verduidelik wat gesondheid, siekte en seksualiteit in tradisionele Afrika beteken. Tradisionele Afrika persepsies van die oorsake van siekte (God, die voorvaders, hekse, "besoedeling" en kieme), persepsies van seksualiteit, die belangrikheid daarvan om kinders te hê, kulturele gelowe wat die gebruik van kondome inhibeer, die belangrikheid van die gemeenskap in die lewe van die Afrikaan, asook die kontroversiële kwessie rondom vertroulikheid in Afrika word bespreek. Die implikasies vir VIGS versorging en berading in Afrika word ondersoek, en voorstelle oor hoe om tradisionele gelowe en gebruike tot die voordeel van VIGS voorligting te gebruik, word gemaak.
Africa is not doing well in her battle against HIV/AIDS. Seventy percent ( 24.5 million) of all the people in the world with HIV live in sub-Saharan Africa, and South Africa in particular was referred to as "the epicentre of the epidemic" at the XIII ${ }^{\text {th }}$ International AIDS conference which was held in Durban in 2000. South African nurses are faced with an unprecedented crisis. Hospitals are inundated with very sick and dying AIDS patients. Nurses who have become accustomed to the healing wonders of medical science and technology find themselves in trouble because the goals of healing and curing can no longer be reached. The nurse's role as healer has shifted to a great extent to that of caregiver, counsellor and educator.

AIDS also calls for nurses to move away from the strict Western-based bio-medical model to include and understand pa- tients who come from a traditional African background. The people of Africa experience the world in a very special and different way than Westerners do. Western-based HIV/AIDS care, counselling and education programmes will never succeed if the diverse cultural and belief systems in Africa are not understood and integrated into such programmes.

The purpose of this article is to review relevant aspects of the traditional African worldview, ${ }^{2}$ as well as the implications of these beliefs and customs for the nurse as AIDS counsellor in Africa. In order to render a useful service to his or her traditional African patients, and to prevent the spread of HIV infection, it is in the first place necessary to know what traditional Africans believe are the causes of illness ("do I have control over my health, and can I really prevent illness by taking cer-

'The term Traditional African is used as opposed to the Western belief system. In Africa, where a constant process of westernisation is taking place, many Africans will have a mix of traditional African beliefs and Western beliefs.

'Despite the differences between Africans from different cultures in terms of geography, linguistics, religiosity and ways of life, there is a dominant socio-religious philosophy shared by all Africans. To talk of an overarching African perspective or African worldview that can be distinguished from a Western and an Eastern perspective is therefore possible (Gyeke, 1987; Okwu, 1978; Sow, 1980). 
tain actions?"). It is also important to know if preventative methods recommended by the nurse (such as condom use) correspond with the patient's believe system ("how can I use condoms if sex and procreation symbolises immortality through children?"). To successfully counsel and care for patients, it is also imperative for the nurse to know how his or her patient feels about individuality versus collectivity ("how can you care for me without taking my group and family needs into account?"). The focus of this article will therefore be on the traditional African's perceptions of illness, sexuality, condom use and community life, and the implications of these concepts for HIV/AIDS care, counselling, education and prevention in the traditional African context.

\section{Traditional African perceptions of the causes of illness}

Without a thorough knowledge of how traditional Africans view illness, the nurse will not be able to render an useful health service to her traditional African patients. It is therefore important to know that traditional Africans do not believe in chance, bad luck or fate. They believe that every illness has an intention and a specific cause, and in order to combat the illness, the cause must be found and counteracted, uprooted or punished. In their quest to understand illness, the questions "why" and "who?" are uppermost in the minds of traditional Africans (Sow, 1980:51). Traditional Africans believe that disease (mental and physical) can be caused by natural causes such as germs, "pollution", failure of human relations, disharmony between a person and the ancestors, a god or spirits, or by witches and sorcerers.

\section{The ancestors and God as causal agents of illness}

In traditional religious systems God is seen as a supreme being or creator who has withdrawn himself from human beings, and is perceived as distant and remote from the people. The living spirits of the deceased ancestors are therefore more important in the everyday existence of African people than God, who is believed to have left people to fend for themselves (Mbiti, 1969:33; McCall, 1995:257; Sow, 1980:5; Viljoen, 1997:617).

Ancestors are seen as benevolent spirits who preserve the honour and traditions of a tribe, and they usually protect their people against evil and destructive forces. Ancestors can, however, punish their people by sending illness and misfortune if certain social norms are violated, if culturally prescribed rites and practices are neglected or incorrectly performed, and when people do not listen to their wise counsel. Some Africans argue that the ancestors do not actually send illness themselves, but merely allow it to happen by withdrawing their protection, leaving the way open for witches and sorcerers to attack them (Beuster, 1997:9-10; Bodibe, 1992:151-152; Hammond-Tooke, 1989:53; Mbiti, 1969:82).

The incidence of ancestor-caused illness is much less frequent than that from other causes, and is seldom serious or fatal. Traditional Africans usually restore the ontological balance between themselves and the ancestors through sacrifices and offerings to the ancestors (Beuster, 1997:10; Bodibe, 1992:150; Hammond-Tooke, 1989:64; Mbiti, 1969:83).

\section{Witches and Sorcerers as causal agents of illness}

The day-to-day fate of individual human beings in Africa is regulated and controlled by the complex relations between humans and the invisible but powerful creatures of a psychological "no-man's land" where genies, evil spirits, witches and sorcerers dwell. Knowledge about this no-man's land is especially important for understanding the behaviour of traditional Africans because nearly all forms of illness, disease, conflict, suffering, misfortunes, accidents and death are ascribed to this level (Sow, 1980:6; Viljoen, 1997:618-619).

Most Africans recognise both an immediate cause as well as an ultimate cause for disease or misfortune. For example, a patient may fully understand that her HIV infection was caused by a "germ" and that this is the immediate cause of her illness. However, she will still ask "but why me and not my neighbour? I sleep only with my husband. My neighbour is running around with many men." The only answer that will really satisfy her is that someone, by means of magical manipulation, has "caused" or "sent" the germ to make her sick instead of her neighbour (the personal or ultimate cause of the illness). Many black people, therefore, consult both traditional healers and biomedical professionals for the same condition: While the traditional healer is consulted to diagnose the personal cause of the condition (eg bewitchment) or to prevent a recurrence of the illness (eg by performing a ritual), a Western doctor is consulted for medication to treat the condition symptomatically (Hammond-Tooke, 1989:83; Herselman, 1997:41; Mbiti, 1969:169; Van Dyk, 2001:108). If nurses do not understand this belief in immediate and ultimate causes of illness, they may feel threatened and have the erroneous idea that black people do not "trust white medicine".

Witches or sorcerers are usually blamed for illness and misfortune in traditional African societies (Felhaber, 1997; HammondTooke, 1989:73). In his research conducted in a conservative Ciskeian rural area in South Africa, Hammond-Tooke (1989:123) found that traditional healers divined (or diagnosed) the causes of illness and misfortune as follows: $72 \%$ of the cases were divined to be caused by witches or sorcerers; $8 \%$ by the ancestors and about $17 \%$ by "non mystical" factors such as drunkenness and accidents. In an urban area the figures differed, with $45 \%$ being attributed to witchcraft or sorcery, $7 \%$ to ancestors and $48 \%$ to non mystical factors.

\section{Pollution as cause of illness}

Not all illnesses are believed to be caused by the wrath of ancestors or the conspiracies of witches and sorcerers. Illness can also result from certain everyday life conditions such as pollution or ritual impurities. Pollution occurs when a person often through no fault of his or her own - finds him or herself in a state of ritual impurity. Such states of impurity or pollution are usually associated with death (eg. handling of corpses, widows who are not cleansed), the reproductive system (eg. menstruation, abortion, miscarriage, the birth of twins), the completion of a long journey, and intercourse (in particular sex with a prohibited person). It is, for example, believed that if a man has sexual intercourse with a woman during menstruation, "bad blood" rushes to his head, and causes delirium (Beuster, 1997:12; Bodibe, 1992:156; Felhaber, 1997; Green, 1994; 
Hammond-Tooke, 1989:91-92). Pollution is usually expelled by cleansing methods, such as enemas and emetics.

\section{Germs as cause of illness}

Traditional Africans do believe that some diseases (such as colds, influenza, diarrhoea in children, STD's and malaria) are caused by natural causes such as "germs" (Felhaber, 1997). Traditional Africans accept that STD's (such as syphilis and gonorrhea) are transmitted through sexual intercourse and that it can be prevented by hehavioural change (Green, 1994). Unfortunately, the connection between STD's, AIDS and sexual behavioural change are often not made in Africa.

\section{Implications of the perception of illness on health education in the HIV/ AIDS context}

To achieve success, health care professionals working in Africa should recognise the traditional African perceptions of the causes of illness and incorporate these beliefs into their HIV/AIDS care and counselling programmes.

\section{God, the ancestors and AIDS}

There are no indications in the literature that AIDS is ever ascribed by traditional Africans to the wrath of ancestors or to God's punishment. While traditional Africans do not believe that God is responsible for AIDS, the influence of Christianity can however be seen in the beliefs of some black Christians who believe that AIDS is God's punishment for immorality and sins.

\section{Witchcraft as Causal Agent of HIV/AIDS}

Witchcraft is believed to be the causal agent in HIV transmission, AIDS and death in many African countries, especially among the rural poor or least-educated people (Boahene, 1996:613; Bond, 1993:3; Yamba, 1997:202). More than 25\% Zambian subjects in Yamba's study ascribed sexually transmitted diseases (STD's) to witchcraft. "Why else", they argued, "would two men be exposed to the same woman and yet one would become infected while the other would not?"

Accusations of witchcraft and sorcery mostly occur when the harmony of a group is threatened or disturbed because of conflict, jealousy, unhealthy competition and tensions that arise in close community life (Beuster, 1997:10-12; Hammond-Tooke, 1989:81). Africa's harmony was hugely disturbed by AIDS that brought the untimely death of young people as well as an unprecedented rise in the overall death toll. In African societies, death is only accepted as natural when old people die, but most other cases where "the queue of dying is jumped", death is seen as punishment or the work of evil spirits and witches (Okwu, 1978:2; Yamba, 1997:202). The psychological function of blaming witchcraft for the breakdown of African societies is therefore understandable: Witchcraft accusation is an attempt to make sense of existence in the era of HIV/AIDS (Yamba, 1997:203). To blame external factors such as witches and sorcerers for AIDS has a protective function, because it prevents feelings of guilt and it alleviates anxiety. Belief in witches also helps people to impose meaning on the things that happen to them and provides answers that science cannot give, such as an explanation of the personal or the ultimate cause of illness.
According to Seeley, Wagner, Mulemwa, Kengeya-Kayondo and Mulder (1991:209) witchcraft beliefs are both an expression and a resolution of a community need to explain why some people who are "at risk" do not contract AIDS and why some people die faster than others. Attributing HIV infection to witcheraft may also help the bereaved family to avoid feeling stigmatised by their community (Campbell \& Kelly, 1995:368). Ironically, Boahene (1996:613) found that people who believe that AIDS is caused by witches, are more likely to be supportive of HIV/AIDS patients because the patients became infected with the virus through sources "beyond their control".

However, witchcraft beliefs also have very negative implications for AIDS counselling and education in Africa. The belief that everything that happens to a person can be attributed to external, supernatural beings or powers, implies that individuals cannot be held responsible or accountable for their own behaviour, and that personal initiative in searching for solutions is repressed (Viljoen, 1997:619). Boahene (1996:613) found that many people in Africa do not consider their own behaviour as a possible reason for HIV infection, and because of this misconception, they do not appreciate the need for using HIV preventive methods. A patient may, for example, say: "This is not my fault. She (girlfriend) bewitched me because she was jealous of my wife".

According to Hammond-Tooke (1989:85) witch-blaming may be a healthy psychological move for the victim, but at a very high cost, often death, for the accused. There are still many examples of witches being hunted down and killed in Africa. And it is often feared that accusations of witchcraft may follow the disclosure of a positive HIV test result if confidentiality is broken (Seeley et al. 1991:209).

Witchcraft beliefs can, however, not be ignored by health care professionals working in Africa. For nurses to ignore and ridicule traditional witchcraft beliefs, would result in losing patients. These beliefs should rather be taken into account and integrated into AIDS prevention programmes. Programmes should, for example, recognise the belief that the personal or ultimate cause of an illness may be witchcraft, but the fact should be stressed that the immediate cause is a "germ" which is sexually transmitted. In her counselling of traditional Africans in South Africa, Zazayokwe (1989) dealt successfully with the problem of causality by telling people that they may know where the HIV infection originated, but that she knows what the disease does inside the body and how they can prevent contracting it. In their research in Uganda, Seeley et al. (1991:209) found that, as AIDS has become more widespread, an explanation that combines scientific fact and witchcraft is used more often. The Rakai of Uganda, for example, are aware that HIV is sexually transmitted, but they attribute the chance of being infected through a sexual act to the power of witchcraft.

Green, Jurg and Dgedge (1993:265) found that many traditional Africans believe that witches or sorcerers use sexual intercourse as the contact point for their medicine or spells to infect people with STD's and AIDS. And throughout the ages, traditional Africans have had their own forms of prophylaxis against witches and sorcerers: To protect themselves against diseases, misfortune and death, they wear charms or amulets believed to have preventive and protective powers (Hammond-Tooke, 1989:78; Okwu, 1978:2). (Nurses often see babies in hospitals wearing protective strings around their waists and necks.) One may therefore ask why - in cases of casual sex - the condom cannot be introduced as preventive charm to block the sexual 
contact point against the evil spells of witches. The help of traditional healers should be asked to "fortify" the condoms with protective power and to distribute them among the community as protective charms. This will encourage traditional Africans to take responsibility for the immediate cause of HIV infection by obstructing the entry point of evil or HIV.

\section{Pollution and HIV/AIDS}

Although AIDS is not ascribed to states of pollution or ritual impurities, some of the sexual prohibitions make sense for HIV prevention programmes. Prohibitions such as sexual intercourse with a woman during menstruation (she may be HIV positive), with a widow before she is cleansed (her husband might have died of AIDS), or with women who have had an abortion or miscarriage, should be encouraged to prevent HIV infection.

\section{The STD-AIDS connection}

Although traditional Africans accept that STD's are caused by "germs" which are sexually transmitted, they often do not see HIV/AIDS as a sexually transmitted disease. They can therefore not understand why they have to change their sexual practices to prevent HIV infection. One of the main reasons why it is so difficult for traditional Africans to see HIV infections as sexually transmitted, is because the symptoms of HIV infection have nothing to do with the sexual organs. They believe that the place where a germ or disease enters the body is the body-part which becomes sick (the genitalia are usually affected in the case of syphilis). HIV attacks everything except their sexual organs - "how then" do they ask "can HIV be sexually transmitted?" (Van Dyk, 1999:130).

The AIDS message should therefore be strongly linked to STD prevention in Africa. The knowledge and help of traditional healers should be actively used in the control and prevention of STD's (and therefore also indirectly of HIV infection) (Green et al. 1993:271). Traditional healers should also actively try to convince their patients that HIV is sexually transmitted.

Traditional healers are consulted by many African patients for STD treatment, and they are particularly competent in handling STD's. Traditional healers often give sound biomedical advice to their STD patients, which is also conducive to the prevention of HIV infection. Among other things they advise patients to abstain from sex while undergoing STD treatment; to choose healthy partners unlikely to have STD's; not to have sex with prostitutes and soldiers; and to locate and treat all recent sexual partners (Green, 1994).

But even if traditional Africans are convinced that HIV is sexually transmitted, they still find it very difficult to use condoms.

\section{Traditional African perceptions of sexuality and condom use}

Condoms are not very popular in Africa. Green (1994) found that although AIDS awareness was reasonablely high in Uganda in 1993, and although millions of condoms had been distributed, the percentage of Ugandan men regularly using condoms was about $3 \%$ at that time. Taylor (1990:1023) similarly found that although the people of Rwanda were well aware of AIDS and had modified their sexual behaviour, none of the respondents in his study reported the use of condoms during intercourse. The tremendous increase in HIV cases in South Africa over the last few years, indicates that condom use is also not very popular in South Africa.

Many Western authors erroneously ascribe this lack of condom use in Africa to promiscuity, permissiveness and to a lack of moral and religious values. This clearly illustrates a lack of understanding of the African philosophy behind sexuality and a disrespect for cultural beliefs. The challenge for health care professionals is not to condemn Africa. but to make the hidden cultural logic behind the resistance to condoms known, and to find ways to work with or around it (Scott \& Mercer, 1994:85). For health care professionals to understand the traditional African's reluctance to use condoms, it is in the first place necessary to know what sex means in the traditional African context, as well as some of the cultural reasons for not using condoms.

\section{The importance of having children: Personal Immortality and day-to-day functioning}

Sex does not only serve a biological function in African societies: For the traditional African, sex also conquers death and symbolises immortality. It is extremely important for traditional Africans to acquire personal immortality through their children. According to Mbiti (1969:25), history does not move forward into the future in traditional African thought, but backwards in time toward the "Zamani" - the Swahili word for the past. As a person grows older, he moves gradually from the "Sasa" (the now-period that represents a person's present experiences) to the Zamani. After physical death, a person continues to exist in the Sasa period as the "living-dead" for as long as he is personally (by name) remembered by relatives and friends who knew him during his life and who has survived him. So long as he is alive in the memories of those who knew him, he is in a state of personal immortality. Mbiti explains this as follows:

Unless a person has close relatives to remember him when he has physically died, then he is nobody and simply vanishes out of human existence like a flame when it is extinguished. Therefore it is a duty, religious and ontological, for everyone to get married; and if a man has no children or only daughters, he finds another wife so that through her, children (or sons) may be born who would survive him and keep him (with the other living-dead of the family) in personal immortality (Mbiti, 1969:26-27).

To be forgotten after one's death and to be cast out of the Sasa period into the spirit world of the Zamani, is the worst possible punishment for a traditional African.

Procreation is therefore one way of ensuring that a person's personal immortality is not destroyed. According to Mbiti (1969:26) the failure to bear children is for an African woman worse than committing genocide. She has not only become the dead end for the genealogical line, but also for herself. When she dies, nobody of her own immediate blood will be there to "remember" her, to keep her in the state of personal immortality: she will simply be "forgotten". The Shona ethnic group in rural Zimbabwe believes that those who die childless cannot be accepted into the spirit world of the ancestors, and must wander the earth as evil, aggrieved or haunted spirits (Mutambirwa in Scott \& Mercer 1994:86).

For the traditional African, children are not only valued for ensuring immortality. They are also very important in the dayto-day existence, because traditional Africans can only pros- 
per on the land of their ancestors if they have many wives and children to help them work their lands. In Africa, a man's wealth depends upon the growth of his tribe. To have many children, is to be considered a rich man. It is therefore understandable that traditional Africans will be very suspicious of any device (such as a condom) which will deprive them from personal immortality and earthly wealth.

\section{The belief that condoms block the "gift of self"}

Apart from social and political reasons, there are also deep rooted cultural beliefs against the use of condoms in some parts of Africa. Taylor (1990:1023) found that the lack of condom use in Rwanda, had nothing to do with ignorance, but with a very specific Rwandan sexual belief. Rwandans believe that the flow of fluids involved in sexual intercourse and reproduction represent the exchange of "gifts of self"which they see as very important in a relationship. They believe that the use of condoms will block this important flow between two partners that may also block the flow of fertility, and cause all sorts of sickness. Many Rwandan women fear that the condom might remain in the vagina after intercourse and that they risk becoming "blocked beings." In a culture where health and pathology are conceived in terms of "flow" and "blockage" it is understandable that women cannot imagine how a "blocking" device could also be a healthy device.

\section{The belief that condoms prevent the "ripening of the fetus"}

There is a widespread belief in many parts of Africa, such as East Africa, Zaire and among the Zulus in South Africa, that repeated contributions of semen are needed to form or "ripen" the growing fetus in the womb and that condoms therefore interfere in the process of natural fetal development. It is also believed that semen contains important vitamins which are necessary for the continued physical and mental health, beauty and future fertility of women (Heald, 1995:498; Ngubane, 1977; Schoepf, 1992:231). Within this traditional frame of reference, the use of condoms is inconceivable because it is perceived as harmful to the health of babies and their mothers.

Merely telling or advising people to use condoms will never work in traditional Africa. Health care professionals should find innovative ways to promote condom use while taking cultural beliefs and customs into account.

\section{Implications of the perception of sex and condoms for AIDS Education}

Once the importance of personal immortality and the value of children in the lives of Africans is understood, Western health care professionals can appreciate why convincing Africans to use condoms is so difficult, and why African women often insist on having children, even if they are found to be HIV positive.

Health care professionals must realise that population control will always remain a sensitive issue in Africa because it negatively impacts on the growth of a tribe, it deprives parents of needed labour and it undermines traditional beliefs and values (Hickson \& Mokhobo, 1992:13). Instead of telling people in Africa to use condoms (and inevitable to prevent pregnancy), it is necessary to tell them how to protect themselves from
STD's and HIV while sometimes allowing "unprotected" sex to make children. Although this solution is imperfect, it is more realistic than advising people to abstain from procreation, and it would at least reduce the risk of partner infection and perinatal transmission in stable relationships (Schoepf, 1992:233).

While having many children is still important for Africans, many women in Africa nowadays do accept the idea of birth spacing and maternal protection. The fact that HIV has such a devastating effect on newborn infants, is of great concern to many traditional healers in Africa because they realise that AIDS may jeopardise future generations, and indirectly also the immortality of their tribe. These devastating effects of HIV on unborn babies should therefore be emphasised in AIDS education programmes as an incentive for change (Green, 1994; Schoepf, 1992:230).

Health care professionals should be flexible in their HIV prevention messages by taking cultural customs and behaviour into account. For example, due to their cultural beliefs that "condoms block the gift of self", Rwandans will probably never agree to using condoms, and AIDS educators should rather spend their energy looking for other ways to prevent the spread of HIV. Existing cultural forms of sexual intercourse should be investigated and encouraged if they seem to be safe, even though Western educators may find them strange. For example, Taylor (1990:1027) described a safe, but exotic form of sexual intercourse practised by Rwandans - called kunyaza - where the focus is on heightening both partners' sexual pleasure while keeping penetration to a minimum. Safe behaviour like this should be identified and encouraged.

Communication and collaboration with traditional healers are also very important when Western health care professionals attempt to change behaviour. In correcting the "ripening of the fetus" belief, Schoepf (1992:232), for example, found an ally in the traditional healers of Kinshasa who were willing to reinterpret traditional beliefs in ways that facilitate condom use. These traditional healers realised that, while their ancestors were correct in stressing the health value of frequent sexual intercourse, they were not confronted by an AIDS epidemic which makes infected semen dangerous. They were therefore prepared to tell their patients that semen should be seen as a metaphor for repeated intercourse. Repeated intercourse is necessary to nourish the mutual love and understanding between the parents, which is essential to provide a nurturing environment for fetal growth. A nurse explained this as follows to a group of mothers: "When the mother knows she is pregnant, the baby is already on its way to growing. The ancient ones meant that the husband should take an interest in his wife and not run around with other women while she awaits the child" (Schoepf, 1992:231). Patients are assured that the actual semen is not needed to "ripen" the fetus and that condoms can therefore be used following conception to reduce risks of HIV infection to partners.

Health care professionals working in Africa, should also show tolerance towards "strange" customs such as polygamy, especially if such customs contribute to safer sex practices. Westerners mostly frown upon polygamy in African societies, but (provided that all partners in the polygamous marriage are HIV negative, and faithful to each other), polygamy often helps to prevent or reduce unfaithfulness, prostitution, STD's and HIV. Polygamy often provides a healthy alternative or solution to problems inherent in certain cultural customs. In some African societies, for example, sexual intercourse between a husband and his wife is prohibited while she is pregnant and this absti- 
nence is observed until after childbirth or in some cases even after the child is weaned. In such situations, polygamy prevents husbands from turning to casual sex. Polygamy is also valuable in modern times when African men are often forced to seek work in the cities and towns. If a husband has several wives, he can afford to take one at a time to live with him in the town, while the other wife or wives remain behind to care for the children and family property (Mbiti, 1969:142-143). In societies where polygamy is practiced, AIDS educators are wasting their time when advocating monogamy: Much more will be achieved by emphasising loyalty and fidelity between a husband and all his wives and by discouraging sex outside that group.

\section{The importance of community life in traditional Africa}

The community plays a very important role in the life of traditional Africans. Traditional African beliefs rest on principles such as the value of the collective interest of the group, the survival of the community or tribe, and union with nature. The traditional African cannot exist alone: his or her identity is totally embedded in his or her collective existence (Sow 1980:7). According to Mbiti (1969:108) "whatever happens to the individual happens to the whole group, and whatever happens to the whole group happens to the individual."

\section{Implications of the importance of community involvement for HIV/AIDS care and counselling}

Community values should be kept in mind by nurses working in Africa. Healing in Africa always takes place in a social setting where the patient is accompanied by members of his or her family who understand, support and accept the patient (Bodibe, 1992:154; Chipfakacha, 1997:420). Healing ceremonies which use relatives and incorporate the guidance and cooperation of the ancestors should also be used in the treatment or handling of AIDS patients (Hickson \& Mokhobo, 1992:19-20). Dancing, singing, drumming, rituals and healing ceremonies should be encouraged because the dramatisation enables patients to express their emotions, to overcome anxiety, and to accept and integrate what may seem like a threatening part of him- or herself. To incorporate the family and community also has the additional benefit that the fears and emotions of the family can be attended to. Storytelling, dancing, drama and singing are not only helpful in therapy, they are also very powerful mediums of education to bring the HIV/AIDS message across.

Already existing community resources such as community elders should be used in the fight against HIV transmission. Willing and enthusiastic people within the communities should be identified and educated to work as peer counselors. The strength and autonomy of African women, especially as presented in women's groups, should also not be overlooked. The solidarity of women in rural African communities may be their greatest source of strength for coping with the AIDS epidemic.

AIDS care and counselling programmes cannot succeed in Africa without collaboration with traditional healers. Traditional healers have a very important role to play in the care and support of AIDS patients, their families and AIDS orphans. Na- tional health systems will not be able to cope with the high AIDS toll in Africa, and it will therefore in many cases be the responsibility of traditional healers to advise people about proper home care, to treat opportunistic infections, to counsel young people about HIV prevention and to give psychological and spiritual support to those living and dying with AIDS (Green et al. 1993:262).

\section{Confidentiality: A controversial issue in Africa}

Nurses should be very sensitive to the issue of confidentiality in Africa. Although it may seem that Africans usually share all their experiences with one another, normative regulations exist as to which kinds of information can be shared, and with whom. African people are especially concerned about secrecy and confidentiality where AIDS is concerned, because they often fear rejection by the community, and even death, if their HIV status becomes general knowledge. In Lie and Biswalo's (1994:144) study, 98\% of the subjects indicated that secrecy and confidentiality are very important to them. They pointed out that they would prefer to talk to somebody "who can keep a secret" about their HIV status. Such people are usually trusted relatives, medical personnel, religious leaders and traditional healers. The critical issue according to Lie and Biswalo, is who should be informed and how. This should be done in such a way as to minimise the risk of rejection and to maximise the mobilisation of social support and existing coping resources. It is therefore a major challenge to the nurse

to identify, in cooperation with the HIV-infected person, which significant others should be informed, in what sequence and by whom.

\section{Conclusion: How to use African beliefs and customs to the advantage of AIDS care and counselling}

When working in Africa, nurses should resist the temptation to discard all traditional African beliefs and practices as ridiculous, superstitious and harmful, and use some of these beliefs to the advantage of AIDS care and counselling. Airhihenbuwa (1989:60-62) proposed the P-E-N model according to which traditional cultural health beliefs and behaviour can be categorised as positive $(P)$, exotic $(E)$ or negative $(N)$ and treated accordingly.

\section{Encourage Positive Cultural Behaviour}

According to the PEN model, positive cultural beliefs and behaviours are values and behaviours which are known to be beneficial and should be encouraged and reinforced. Examples of positive values and behaviour are those which discourage or forbid sexual intercourse before marriage; immediately after birth or during pregnancy; with widows (the husband might have died of AIDS), and with women who have aborted or miscarried. Also positive is the belief that intercourse with a person with a STD is dangerous, and values that encourage traditional "thigh sex" or other forms of non-penetrative intercourse, which is sometimes practised by the youth, unmarried people and when a wife is menstruating (Airhihenbuwa, 1989:63; Green et al. 1993:277; Green et al. 1995:507). 


\section{Accept and Respect Exotic Cultural Behaviour}

Exotic behaviours are traditional African customs and behaviours that are unfamiliar and strange to Westerners, but are not harmful to health. These exotic behaviours, such as polygamous marriages, cultural rituals, ceremonies and herbal remedies, need not to be changed and should be respected. Nurses should appreciate the importance of rituals for the identity and corporate existence of people in Africa. However, if they find that rituals (such as circumcision and tribal markings) are harmful to people's health, they should not attempt to change or put a stop to the ritual but rather suggest ways to make it safer (eg. to use clean instruments to assure that HIV is not transmitted). Traditional Africans will never stop their rituals, but they will be prepared to conduct it in a safer way if they know why and how to do it.

\section{Change Negative Cultural Behaviour}

Although nurses should take care not to interfere in cultural beliefs and behaviour, some misconceptions and traditional behaviours are indeed harmful to people's health, and attempts should be made to change these. Examples of negative behaviour include the following: Having multiple sexual partners; cleansing rituals such as in Zambia and Botswana whereby a widow has to have sexual intercourse with a close relative of her deceased husband to cleanse her of her husband's spirit (Campbell \& Kelly, 1995:370; Chipfakacha, 1997:424; Hickson \& Mokhobo, 1992:12); the custom of inheriting the wife of a deceased brother (who might have died of AIDS); the impregnation of an impotent or sterile brother's wife; the use of sex to express hospitality where the host offers his wife or sister to a visiting guest (Mbiti, 1969:144), and the practice of "dry sex" by African women (where the vagina is dried out with substances such as herbs, leaves, Jik, Dettol etc.) to heighten the sexual experience for men, or more traditionally to "clean the temple for creation" from undesirable vaginal secretions (Moses \& Plummer, 1994:125; Runganga \& Kasule, 1995:640). Ways should also be devised to make the preparation and cleansing of bodies for burial safer. In Sudan, for example, undigested food and excreta are removed from corpses by hand - a procedure which was implicated in the 1976 and 1979 Ebola outbreaks in Zaire and Sudan (Garrett, 1995:336).

In their role as AIDS educators in Africa, nurses are implored not to merely criticise and condemn African beliefs, but to try and understand the philosophical reasons behind these beliefs and to take it into account when caring for and counselling people from Africa.

\section{References}

AIRHIHENBUWA, CO 1989: Perspectives on AIDS in Africa: Strategies for prevention and control. AIDS Education and Prevention. 1(1):57-69.

BEUSTER, J 1997: Psychopathology from a traditional Southern African perspective. UNISA Psvchologia. 24(2):4-16.

BOAHENE, K 1996: The IXth International Conference on AIDS and STD in Africa. AIDS Care, 8(5):609-616.

BODIBE, RC 1992: Traditional healing: An indigenous approach to mental health problems. (In: Uys, J Ed.1992: Psycho- logical counselling in the South African context. Cape Town: Maskew Miller Longman, pp 149-165.)

BOND, G 1993: Death, dysentery and drought: Coping capacities of households in Chiawa. (Paper presented at the Institute of Africa Studies, 1993: Lusaka, Zambia).

CAMPBELL, T \& KELLY, M 1995: Women and AIDS in Zambia: A review of the psychosocial factors implicated in the transmission of HIV. AIDS Care. 7(3):365-373.

CHIPFAKACHA, VG 1997: STD/HIV/AIDS knowledge, beliefs and practices of traditional healers in Botswana. AIDS Care, 9(4):417-425.

FELHABER, T (ED.) 1997: South African traditional healers' primary health care handbook. Cape Town: Kagiso.

GARRETT, L 1995: The coming plague: Newly emerging diseases in a world out of balance. New York: Penguin.

GREEN, EC 1994: AIDS and STD's in Africa. Bridging the Gap between Traditional Healing and Modern Medicine. Pietermaritzburg: University of Natal Press.

GREEN, EC; JURG, A \& DGEDGE, A 1993: Sexually-Transmitted Diseases, AIDS and traditional healers in Mozambique. Medical Anthropology. 15:261-281.

GREEN, EC; ZOKWE, B \& DUPREE, JD 1995: The experience of an AIDS prevention program focused on South African traditional healers. Social Science and Medicine. 40(4):503-515.

GYEKE, K 1987: An Essay on African philosophical thought: The Akan conceptual scheme. Cambridge: Cambridge University Press.

HAMMOND-TOOKE, D 1989: Rituals and medicines. Johannesburg: AD. Donker.

HEALD, S 1995: The power of sex: Some reflections on the Caldwells' African sexuality thesis. Africa. 65(4):489-505.

HERSELMAN, S 1997: A multicultural perspective on health care.(In: M. Bouwer, M. Dreyer, S. Herselman, M. Lock \& S. Zeelie Eds. 1997: Contemporary Trends in Community Nursing. Johannesburg: Thomson, pp 28-53).

HICKSON, J \& MOKHOBO, D 1992: Combatting AIDS in Africa: Cultural barriers to effective prevention and treatment. Journal of Multicultural Counselling and Development. 20(1):1122.

LIE, GT \& BISWALO, PM 1994: Perceptions of the appropriate HIV/AIDS counsellor in Arusha and Kilimanjaro regions of Tanzania: Implications for hospital counselling. AIDS Care. 6(2):139-151.

MBITI, JS 1969: African religions and philosophy. London: Heinemann.

MCCALL, JC 1995: Rethinking ancestors in Africa. Africa. 65(2):256-270. 
MOSES, S \& PLUMMER, FA 1994: Health education, counselling and the underlying causes of the HIV epidemic in subSaharan Africa. AIDS Care, 6(2): 123-127.

NGUBANE, HS 1977: Body and mind in Zulu medicine. London: Academic Press.

OKWU, A 1978: Dying, death, reincarnation and traditional healing in Africa. (Paper presented at the Twenty-first Annual meeting of the African Studies Association, Baltimore, Maryland).

RUNGANGA, AO \& KASULE, J 1995: The vaginal use of herbs/substances: An HIV transmission facilitatory factor? AIDS Care. 7(5):639-645.

SCHOEPF, BG 1992: AIDS, sex and condoms: African healers and the reinvention of tradition in Zaire. Medical Anthropology. 14:225-242.

SCOTT, SJ \& MERCER, MA 1994: Understanding cultural obstacles to HIV/AIDS prevention in Africa. AIDS Education and Prevention. 6(1):81-89.

SEELEY, J; WAGNER, U; MULEMWA, J; KENGEYAKAYONDO, J \& MULDER, D 1991: The development of a community-based HIV/AIDS counselling service in a rural area in Uganda. AIDS Care. 3(2):207-217.

SOW, I 1980: Anthropological structures of madness in Black Africa. New York: International Universities Press.

TAYLOR, CC 1990: Condoms and cosmology: The 'fractal' person and sexual risk in Rwanda. Social Science and Medicine. 31(9): 1023-1028.

VAN DYK, AC 1999: AIDS Care and Counselling. Cape Town: Maskew Miller Longman.

VAN DYK, AC 2001: HIV/AIDS Care and Counselling: A multidisciplinary approach, $2^{\text {nd }}$ edition . Cape Town: Pearson Education.

VILJOEN, HG 1997: Eastern and African perspectives.(In: W.F. Meyer, C. Moore, \& H.G. Viljoen, Eds., Personology: From individual to ecosystem. Johannesburg: Heinemann pp 591627).

YAMBA, CB 1997: Cosmologies in turmoil: Witchfinding and AIDS in Chiawa, Zambia. Africa. 67(2):200-223.

ZAZAYOKWE, M 1989: Some barriers to education about AIDS in the black community. (Paper presented at an AIDS training course of the South African Institute for Medical Research, 1997: Johannesburg). 